\title{
Detection of cytomegalovirus infections by PCR in renal transplant patients
}

S.C.B. Costal S.R.P. Miranda²,

G. Alves ${ }^{1}$,

C.L. Rossi ${ }^{3}$,

L.T.M. Figueiredo ${ }^{4}$ and F.F. Costa ${ }^{2}$

\author{
${ }^{1}$ Departamento de Clínica M édica, ${ }^{2} \mathrm{H}$ emocentro, and \\ ${ }^{3}$ Departamento de Patologia Clínica, Faculdade de Ciências Médicas, \\ Universidade Estadual de Campinas, Campinas, SP, Brasil \\ ${ }^{4}$ Departamento de Clínica M édica, Faculdade de M edicina de Ribeirão Preto, \\ Universidade de São Paulo, Ribeirão Preto, SP, Brasil
}

\section{Correspondence}

S.C.B. Costa

Disciplina de Medicina Interna

Departamento de Clínica Médica

FCM, UNICAMP

13081-970 Campinas, SP

Brasil

Fax: + 55-19-289-3114

E-mail: ferreira@ turing.unicamp.br

Publication supported by FAPESP.

Received April 28, 1998

Accepted May 7, 1999

\section{Abstract}

Cytomegalovirus (CMV) is the single most important infectious agent affecting recipients of organ transplants. To evaluate the incidence and the clinical importance of CMV infection in renal transplants in Brazil, 37 patients submitted to renal allograft transplants were tested periodically for the presence of cytomegalovirus DNA in urine using the polymerase chain reaction (PCR), and for the presence of IgM and IgG antibodies against CMV by enzyme-linked immunosorbent assay (ELISA) and indirect immunofluorescence (IFI). The PCR-amplified products were detected by gel electrophoresis and confirmed by dotblot hybridization with oligonucleotide probes. Thirty-two of the 37 patients (86.4\%) were positive by at least one of the three methods. In six patients, PCR was the only test which detected the probable CMV infection. Ten patients had a positive result by PCR before transplantation. In general, the diagnosis was achieved earlier by PCR than by serologic tests. Active infection occurred more frequently during the first four months after transplantation. Sixteen of the 32 patients (50\%) with active CMV infection presented clinical symptoms consistent with CMV infection. Five patients without evidence of active CMV infection by the three tests had only minor clinical manifestations during follow-up. Our results indicate that PCR is a highly sensitive procedure for the early detection of CMV infection and that CMV infection in renal transplant patients is a frequent problem in Brazil.

\section{Introduction}

Cytomegalovirus (CMV) infection is an important cause of morbidity and mortality in immunosuppressed patients, particularly among allograft recipients, whose number has increased markedly in recent years. The ubiquity of this virus, its propensity to be reactivated when host defenses are compro-

\author{
Key words \\ - Transplantation \\ - CMV \\ - PCR \\ - Kidney
}


illness (overt CMV disease) ranging from high fever to death. The rapid and specific diagnosis of active CMV infection in these patients is important since its manifestations may resemble those of transplant rejection but require distinct management (1-6). Several procedures for the detection of CMV are available, including conventional virus culture, shell-vial, serology tests, antigenemia and PCR (7-12). In this paper we report the prevalence and clinical impact of CMV infection identified by serological tests and by PCR in a Brazilian population of kidney transplant patients.

\section{Material and Methods}

\section{Patients}

Thirty-seven patients submitted to kidney transplantation at the Kidney Transplant Unit of the Department of Internal Medicine, University Hospital, State University of Campinas, SP, Brazil, were studied prospectively over a two-year period. Informed consent was obtained from all patients and the protocol was approved by the Hospital's Ethics Committee.

The immunosuppressive regimen used during the study included corticosteroids, azathioprine, and cyclosporine. Episodes of rejection were documented by renal biopsy and treated with increased doses of oral corticosteroids for mild episodes and $500 \mathrm{mg}$ intravenous pulses of methylprednisolone, or the monoclonal antibody $\mathrm{OKT}_{3}$, or both, for moderate or severe episodes.

Clinical and laboratory records were reviewed for evidence of symptoms attributed to CMV disease.

\section{Clinical specimens}

Urine. Urine samples were obtained from renal allograft donors and recipients immediately prior to transplantation and from recipients once a month for approximately one year post-transplant.

Serum. Serum samples were collected at the same time as urine specimens and were tested by serological methods for CMV (enzyme-linked immunosorbent assay (ELISA) and indirect immunofluorescence (IFI)). All specimens for a given patient were analyzed in the same batch.

\section{Serology}

Serum CMV IgG and IgM antibodies were determined by ELISA (13) and IFI (14).

\section{PCR}

CMV DNA determination in urine specimens was carried out by PCR according to the procedure of Demmler et al. (15) using three pairs of primers for amplification. Each pair was designed for the amplification of different regions of the viral genome (16). The reaction buffer contained $50 \mathrm{mM} \mathrm{KCl}$, $10 \mathrm{mM}$ Tris- $\mathrm{HCl}, \mathrm{pH} 8.3,1.5 \mathrm{mM} \mathrm{MgCl}_{2}$, $0.01 \%$ gelatin, $200 \mu \mathrm{M}$ of each of the four deoxynucleotide triphosphates (dATP, dCTP, dTTP and dGTP), $2.4 \mu \mathrm{M}$ of each primer, water and sample $(1.5 \mu \mathrm{l})$, for a total volume of $100 \mu$ l. The reaction mixture was overlaid with $100 \mu$ l of mineral oil and the tubes were placed in a boiling water bath for $7 \mathrm{~min}$. After boiling, $0.5 \mu 1$ ( $2.5 \mathrm{U})$ of Thermus aquaticus (Taq) polymerase was added. The amplification reaction was performed in a DNA Thermal Cycler (Perkin-Elmer/Cetus, Norwalk, CT, USA). The samples were heated to $94^{\circ} \mathrm{C}$ for $90 \mathrm{~s}$ to denature DNA, cooled to $55^{\circ} \mathrm{C}$ for $90 \mathrm{~s}$ for annealing and then heated to $72^{\circ} \mathrm{C}$ for $120 \mathrm{~s}$ for extension. In the final cycle, an extension period of 7 min was done. A total of 40 cycles were performed and $5 \mu 1$ of the amplified product was detected by direct analysis on $2 \%$ agarose minigels and by a dot-blot hybridization assay using oligonucleotide probes. A 159-, 400- and 435-base pair band was seen when 
samples were amplified using IE, LA and MIE primers, respectively.

After electrophoresis, the remaining PCR product was tested by dot-blot. For dot-blot analysis (15), $10 \mu \mathrm{l}$ of the reaction mixture was mixed with $190 \mu 1$ of $2 \mathrm{M}$ sodium chloride and then denatured by adding $10 \mu \mathrm{l}$ of $10 \mathrm{M}$ sodium hydroxide for $15 \mathrm{~min}$. The sample was then neutralized by adding 100 $\mu 1$ of $3 \mathrm{M}$ sodium acetate, $\mathrm{pH}$ 5.5. The DNA was immediately applied to a nylon membrane by vacuum filtration, and the membranes were dried by heating in a vacuum oven at $80^{\circ} \mathrm{C}$ for $1 \mathrm{~h}$ and hybridized with a homologous ${ }^{32} \mathrm{P}$-labeled synthetic oligonucleotide probe in a hybridization solution containing $1 \%$ SDS and $6 x$ SSPE buffer $(0.9 \mathrm{M}$ $\mathrm{NaCl}, 60 \mathrm{mM} \mathrm{NaH}_{2} \mathrm{PO}_{4}, \mathrm{pH} 7.4$, and $6 \mathrm{mM}$ $\mathrm{Na}_{2}$ EDTA) for $18 \mathrm{~h}$. Three 10-min washes were subsequently performed in 6x SSPE and $1 \%$ SDS at room temperature. A final wash was performed in 1x SSPE and $1 \%$ SDS for $3 \mathrm{~min}$ at $65^{\circ} \mathrm{C}$. The bound probe was detected by autoradiography at $-70^{\circ} \mathrm{C}$ for $18 \mathrm{~h}$.

\section{O ccurrence of CMV infection}

Active CMV infection was defined if one or more of the following four conditions were present: 1) two or more positive results for human CMV DNA by PCR in urine, 2) $\mathrm{CMV}$ antibody seroconversion in a subject who was seronegative before the transplant, 3) a four-fold or greater increase in IgG CMV antibodies, and 4) a positive test for IgM CMV antibodies.

Symptoms consistent with CMV disease have been previously described (17-21), and the diagnostic criteria for symptomatic CMV disease used in our study essentially followed the recommendations made by the Workshop on human CMV disease (19). Work-up for microorganisms other than CMV included multiple bacteriological and fungal cultures of blood, urine and sputum, as well as serologic tests and multiple chest
X-rays. CMV isolation was not attempted.

\section{Results}

Based on the criteria used, 32 (86.4\%) of the 37 subjects had laboratory evidence of active CMV infection. In six patients, PCR was the only test, which detected a probable CMV infection. Using this technique, we identified viral DNA in $64.9 \%$ of the transplanted patients. The diagnosis was achieved earlier by PCR than by serologic tests in general, and active CMV infection occurred more frequently in the first four months after transplantation. A diagnosis of active CMV infection was obtained for $51.4 \%$ of the patients by ELISA and for $54.1 \%$ by IFI (Table 1).

Thirty-four of the 37 (91.8\%) renal recipients were seropositive by ELISA before transplantation as were 32 of the 35 donors (91.4\%). One hundred percent of the recipients and their respective donors were found to be CMV seropositive by IFI before the transplant.

Only one of 37 patients was seronegative for CMV (ELISA) and he received a kidney from a seropositive donor. As a result, he developed primary CMV infection after the transplant. Sixteen of the 32 patients $(50 \%)$ with an active CMV infection showed clinical manifestations attributable to CMV disease (Table 2). However, CMV etiology could only be confirmed in three of these patients. All of them had pneumonia, with CMV detected by PCR in bronchoalveolar lavage in two and by lung histopathology in one fatal case. Five previously seropositive patients who did not have an active CMV infection by the adopted criteria had only minor clinical complications during followup.

Prolonged unexplained fever occurring without the discernible involvement of other organ systems, but usually associated with malaise, anorexia, fatigue, night sweats, myalgias and arthralgias, was the most 
Table 1 - Results of serology (ELISA and IFI) and PCR on urine during follow-up of 37 kidney transplant patients who presented active CMV infection.

$\mathrm{D} / \mathrm{R}=$ Donor/receptor; $+=$ positive reaction; $-=$ negative reaction; $*$ the numbers after transplantation indicate the months in which PCR and/or serology were indicative of active CMV infection; SC = seroconversion; Not detected $=$ no seroconversion and/or increase in IgG antibody levels during follow-up.

\begin{tabular}{|c|c|c|c|c|c|c|c|}
\hline \multirow[t]{3}{*}{ Patients } & \multicolumn{2}{|c|}{ Before transplantation } & \multicolumn{5}{|c|}{ After transplantation* } \\
\hline & \multirow[b]{2}{*}{$\begin{array}{c}\text { IgG ELISA } \\
\text { D/R }\end{array}$} & \multirow[b]{2}{*}{$\begin{array}{l}\text { PCR } \\
D / R\end{array}$} & \multirow[b]{2}{*}{ PCR } & \multirow[b]{2}{*}{ IgM ELISA } & \multirow[b]{2}{*}{ IgM IFI } & \multicolumn{2}{|c|}{$\begin{array}{l}\text { Seroconversion and/or } \\
\text { increase in IgG antibody } \\
\text { levels detected by }\end{array}$} \\
\hline & & & & & & ELISA & IFI \\
\hline 1 & $+/+$ & $-1-$ & 7,8 & - & - & Not detected & 8 \\
\hline 2 & $+/+$ & $-1-$ & - & - & - & 4 & 9 \\
\hline 3 & $+/+$ & $-1-$ & $1,2,3,9$ & - & - & Not detected & Not detected \\
\hline 4 & $-1-$ & $-1+$ & 1 & 1 & - & Not detected & Not detected \\
\hline 5 & $+/+$ & $-1-$ & $2,4,6$ & - & - & $2,3,4,6$ & $2,4,6$ \\
\hline 6 & $+/+$ & $-1-$ & $1,3,5,6$ & - & - & Not detected & Not detected \\
\hline 7 & $+/+$ & $-1-$ & - & - & - & Not detected & Not detected \\
\hline 8 & $+/+$ & $-1-$ & 3,6 & $1,2,3,4$ & - & $1,2,3,4,6$ & Not detected \\
\hline 9 & $+/+$ & $-1-$ & 5,7 & - & - & Not detected & 7 \\
\hline 10 & $+/+$ & $-1+$ & 2 & - & - & Not detected & Not detected \\
\hline 11 & $+/+$ & $-1-$ & 2,3 & - & - & Not detected & Not detected \\
\hline 12 & $+/+$ & $-1+$ & $3,4,5,7$ & $2,3,4,5,7$ & - & Not detected & Not detected \\
\hline 13 & $+/-$ & $-1-$ & $2,3,4,5,6$ & $1,2,3,4,5,6$ & $2,3,4$ & $\mathrm{SC}(2)$ & $\mathrm{SC}(2)$ \\
\hline 14 & $+/+$ & $-/-$ & - & - & 2,4 & $2,4,10$ & Not detected \\
\hline 15 & $+/+$ & $-1-$ & $1,2,3,4$ & - & - & Not detected & Not detected \\
\hline 16 & $+/+$ & $-1-$ & $4,6,10$ & - & - & $2,4,6,10$ & $2,4,6,10$ \\
\hline 17 & $+/+$ & $-1+$ & 5 & - & - & Not detected & $5,9,10,11$ \\
\hline 18 & $-1+$ & $-1-$ & - & - & - & Not detected & Not detected \\
\hline 19 & $+/+$ & $-1-$ & - & - & 3,4 & 3,4 & Not detected \\
\hline 20 & $+/+$ & $-1-$ & - & - & - & Not detected & Not detected \\
\hline 21 & $+/+$ & $-1-$ & $2,3,6,8$ & - & 8 & Not detected & Not detected \\
\hline 22 & $+/+$ & $-1+$ & $3,4,8$ & - & - & 3,4 & Not detected \\
\hline 23 & $+/+$ & $-1+$ & 1 & - & 1 & $3,6,7$ & Not detected \\
\hline 24 & $+/+$ & $-1-$ & 3,4 & - & - & Not detected & Not detected \\
\hline 25 & $-1-$ & $-1-$ & - & - & - & Not detected & Not detected \\
\hline 26 & $+/+$ & $-1-$ & - & - & 2,7 & Not detected & Not detected \\
\hline 27 & $+/+$ & $-1+$ & 3 & - & 7 & Not detected & Not detected \\
\hline 28 & $+/+$ & $-/-$ & - & $5,9,11$ & $5,9,11$ & $5,9,11$ & Not detected \\
\hline 29 & $+/+$ & $-1-$ & 3,5 & 3,4 & - & Not detected & Not detected \\
\hline 30 & $+/+$ & $-1-$ & - & - & - & 4 & Not detected \\
\hline 31 & $+/+$ & $-1+$ & 3,4 & 4,5 & 5 & 5 & 4,5 \\
\hline 32 & $+/+$ & $-/-$ & - & - & - & $3,5,6$ & $1,2,3$ \\
\hline 33 & $+/+$ & $-1-$ & - & - & 6 & Not detected & 5,6 \\
\hline 34 & $+/+$ & $-1+$ & 3,5 & - & 5 & 5 & Not detected \\
\hline 35 & $+/+$ & $-/-$ & - & - & - & Not detected & Not detected \\
\hline 36 & $+/+$ & $-1+$ & 1,6 & - & - & 6 & 6 \\
\hline 37 & $+/+$ & $-1-$ & 3 & - & - & 3 & 3 \\
\hline
\end{tabular}


common symptom observed in patients who developed CMV infection (11 patients) (Table 2). All of these patients had fever $\geq 38^{\circ} \mathrm{C}$ for at least one week without other detectable infectious causes. All patients with active CMV infection had at least one of the following manifestations in addition to fever: 1) leukopenia (white blood cells $<4,000$ / $\mathrm{mm}^{3}$ ); 2) thrombocytopenia (platelets $<100,000 / \mathrm{mm}^{3}$ ); 3) hepatitis (serum alanine aminotransferase $>40 \mathrm{IU}$ ) and 4) atypical lymphocytosis $\geq 3 \%$ ).

\section{Discussion}

Cytomegalovirus infection remains a major cause of morbidity and mortality in the immunocompromised patient, and is the most serious problem in organ allograft recipients. The possibility of using specific antiviral therapy to treat CMV infections makes a timely diagnosis imperative (2134). To overcome the time disadvantage of a cell culture assay, investigators have used PCR to amplify CMV specific sequences and have demonstrated its usefulness for monitoring CMV infection in renal trans- plant patients $(25,26)$.

To our knowledge, this is the first study in Brazil to use PCR to detect CMV infection in renal transplant patients. With this technique, we identified viral DNA in $64.9 \%$ of the transplanted patients. The findings of Rowley et al. (25) and Chen et al. (22) suggest that the PCR assay is only capable of detecting CMV viral DNA in patients with an active infection and that it is not positive in seropositive healthy individuals or in seropositive transplant patients without other evidence of active CMV infection. Remarkably, we did not find positive CMV PCR in over 200 urine samples from seropositive healthy adults used as controls (data not shown). The results of our study are comparable to those of Olive et al. (26) who concluded that PCR was more sensitive than ELISA and cell culture in detecting CMV in renal transplant patients.

The predominant clinical feature detected in patients with evidence of active CMV infection was fever $(70 \%)$. Other relevant clinical manifestations included hepatitis with negative tests for hepatitis viruses A, B and $\mathrm{C}$, leukopenia, and interstitial pulmonary in-

Table 2 - Clinical features of patients who developed CMV infection.

(+) Fatal illness.

\begin{tabular}{llr}
\hline Patients & Clinical findings in probable and confirmed* CMV infection & Days after transplantation \\
\hline 6 & Fever, myalgias and cough & 150 \\
10 & Compromised renal function, without cellular rejection & 60 \\
12 & Unexplained fever & 210 \\
13 & Fever, leukopenia, splenomegaly & 30 \\
14 & Generalized lymphadenopathy & 13 \\
16 & Fever, myalgias and cough & 300 \\
17 & Compromised renal function, without cellular rejection & 150 \\
22 & Hepatitis with leukopenia & 90 \\
$23(+)^{*}$ & Fever, dyspnea and interstitial pulmonary infiltration & 30 \\
27 & Leukopenia & 90 \\
28 & Unexplained fever & 330 \\
$29 *$ & Fever and cough & 45 \\
31 & Fever, myalgia and fatigue & 150 \\
$32 *$ & Fever and interstitial pulmonary infiltration & 30 \\
34 & Fever, myalgia and fatigue & 45 \\
36 & Prolonged unexplained fever & 30
\end{tabular}


filtrates associated with detection of CMV in bronchoalveolar lavage and in a lung biopsy by PCR. We also observed compromised renal function in two cases for which a graft biopsy did not demonstrate a well-defined cellular rejection.

In agreement with data in the literature, the clinical manifestations observed in patients who were CMV seropositive before transplantation were not severe and resolved spontaneously, except for one patient (No. 23) who died.

In a previous study conducted in Brazil (35), a CMV infection was diagnosed in $5.3 \%$ of the patients based exclusively on serological methods (complement fixation and IFI). Another study using viral cultures and serological methods (complement fixation and IFI) (36) detected CMV infection in $26 \%$ of the patients. In these two studies, as well as in the present one, there was an absolute predominance of live over dead donors. The different frequencies of CMV infection obtained in these studies probably reflect methodological differences. The first of them (35) was retrospective and based the diagnosis of CMV infection on serological methods that are regarded as somewhat un- reliable. The frequency of CMV infection in the present study was greater than in previous studies $(35,36)$, probably because of the high sensitivity of PCR in detecting CMV together with a longer follow-up period.

In the present study, 32 patients showed evidence of active CMV infection. In 13 $(40.6 \%)$ of them, renal function was compromised one year after the transplant. In five, the graft was unsuccessful, two died and three underwent hemodialysis or peritoneal dialysis. In five of the 37 patients who showed no evidence of active CMV infection or any relevant clinical problems, renal function was maintained one year after the transplant. In view of the small number of patients studied, these results do not permit statistical analysis but show a tendency towards more frequent loss of renal function in patients with active CMV infection.

The utilization of techniques such as PCR that permit the rapid diagnosis of CMV infection improves the chances for implementation of specific antiviral treatment. The finding that $86.4 \%$ of the patients developed CMV infection underscores the frequency of this problem in renal transplant patients in Brazil.

\section{References}

1. Abecassis MM, Koffron AJ, Kaplan B, Buckingham M, Muldoon J P, Cribbins AJ , Kaufman DB, Fryer J P, Stuart J \& Stuart FP (1997). The role of PCR in the diagnosis and management of CMV in solid organ recipients: what is the predictive value for the development of disease and should PCR be used to guide antiviral therapy. Transplantation, 63: 275-279.

2. Rubin RH (1990). Impact of cytomegalovirus infection on organ transplant recipients. Reviews of Infectious Diseases, 12 (Suppl 7): 754-766.

3. Rubin RH, Levin M \& Cohen C (1979). Summary of a workshop on cytomegalovirus infections during organ transplantation. J ournal of Infectious Diseases, 139: 728-734.

4. Rubin RH, Cosimi AB, Tolkoff-Rubin NE, Russell PS \& Hirsch MS (1977). Infection disease syndromes attributable to $\mathrm{cy}$ - tomegalovirus and their significance among renal transplant recipients. Transplantation, 24: 458-464.

5. Rubin RH, Tolkoff-Rubin NE, Oliver D, Rota TR, Hamilton J, Betts RF, Pass RF, Hills W, Szmuness W, Farrell ML \& Hirsch MS (1985). Multicenter seroepidemiologic study of the impact of cytomegalovirus infection on renal transplantation. Transplantation, 40: 243-249.

6. Sweny P (1993). Infection in solid organ transplantation. Current Opinion in Infectious Diseases, 6: 412-416.

7. Chou S (1990). Newer methods for diagnosis of cytomegalovirus infection. Reviews of Infectious Diseases, 12 (Suppl 7): 727-736.

8. Costa SCB, Miranda SRP, Alves G, Rossi CL, Figueiredo LTM \& Costa FF (1994). Donated organs as a source of cytomegalovirus (CMV) in renal transplant patients.
Brazilian J ournal of Medical and Biological Research, 27: 2573-2578.

9. Drew WL (1988). Diagnosis of cytomegalovirus infection. Reviews of Infectious Diseases, 10 (Suppl 3): 468-476.

10. Gleaves CA, Smith TF, Shuster EA \& Pearson GR (1985). Comparison of standard tube and shell vial cell culture techniques for the detection of cytomegalovirus in clinical specimens. J ournal of Clinical Microbiology, 21: 217-221.

11. Shibata D, Martin WJ, Appleman MD, Causey DM, Leedom J M \& Arnheim N (1988). Detection of cytomegalovirus DNA in peripheral blood of patients infected with human immunodeficiency virus. J oumal of Infectious Diseases, 158: 1185-1192.

12. Shuster EA, Beneke J S, Tegtmeier GE, Pearson GR, Gleaves CA, Wold AD \& Smith TF (1985). Monoclonal antibody for 
rapid laboratory detection of cytomegalovirus infections: characterization and diagnostic application. Mayo Clinic Proceedings, 60: 577-585.

13. Demmler GJ (1986). Enzyme linked immunosorbent assay for the detection of IgM class antibodies to cytomegalovirus. J ournal of Infectious Diseases, 153: 11521155.

14. Reynolds DW, Stagno $S \&$ Alford CA (1979). Laboratory diagnosis of cytomegalovirus infections. In: Lennette $\mathrm{EH} \&$ Schmidt NJ (Editors), Diagnosis Procedures for Viral, Rickettsial and Clamydial Infections. 5th edn. American Public Health Association, Inc., New York, 399439.

15. Demmler GJ, Buffone GJ , Schimbor CM \& May RA (1988). Detection of cytomegalovirus in urine from newborns by using polymerase chain reaction DNA amplification. J ournal of Infectious Diseases, 158: 1177-1184.

16. Stenberg RM, Thomsen DR \& Stinski MF (1984). Structural analysis of the major immediate early gene of human cytomegalovirus. J ournal of Virology, 49: 190199.

17. Chatterjee SN \& J ordan GW (1979). Prospective study of the prevalence and symptomatology of cytomegalovirus infection in renal transplant recipients. Transplantation, 28: 457-460.

18. Fryd DS, Peterson PK, Ferguson RM, Simmons RL, Balfour J r HH \& Najarian J S (1980). Cytomegalovirus as a risk factor in renal transplantation. Transplantation, 30: 436-439.

19. Ljungman $P \&$ Plotkin SA (1995). Workshop on CMV disease; definitions, clinical severity scores and new syndromes. Scandinavian J ournal of Infectious Diseases, 99 (Suppl): 87-89.

20. Hibberd PL, Tolkoff-Rubin NE, Cosimi AB, Schooley RT, Isaacson $D$, Doran $M$, Delvecchio A, Delmonico FL, Auchincloss J r H \& Rubinn RH (1992). Symptomatic cytomegalovirus disease in the cytomegalovirus antibody seropositive renal transplant recipient treated with OKT3. Transplantation, 53: 68-72.

21. Peterson PK, Balfour J r HH, Marker SC, Fryd DS, Howard RJ \& Simmons RL (1980). Cytomegalovirus disease in renal allograft recipients: a prospective study of the clinical features, risk factors and impact on renal transplantation. Medicine, 59: 283-300.

22. Chen YT, Mercer GO, Cheigh JS \& Mouradian J Á (1992). Cytomegalovirus infection of renal allografts. Transplantation, 53: 99-102.

23. Griffiths PD \& Whitley RJ (1993). Viral infections in the immunocompromised host. Current Opinion in Infectious Diseases, 6: 417-421.

24. Ho M (1990). Epidemiology of cytomegalovirus infections. Reviews of Infectious Diseases, 12 (Suppl 7): 701-710.

25. Rowley AH, Wolinsky SM, Sambol SP, Barkholt AE \& Andersson J P (1991). Rapid detection of cytomegalovirus DNA and RNA in blood of renal transplant patients by in vitro enzymatic amplification. Transplantation, 51: 1028-1033.

26. Olive DM, Al-Mufti S, Simsek M, Fayez H $\&$ Al Nakib W (1989). Direct detection of human cytomegalovirus in urine specimens from renal transplant patients following polymerase chain reaction amplification. J ournal of Medical Virology, 29: 232-237.

27. Marsano L, Perrillo RP, Flye MW, Hanto DH, Spitzer ED, Thomas J R, Murray PR, Windus DW, Brunt EM \& Storch GA (1990). Comparison of culture and serology for the diagnosis of cytomegalovirus infection in kidney and liver transplant recipients. J ournal of Infectious Diseases, 161: 454-461.

28. Godeaut E, Galezowski N, Berche P, Bonissol C, Debure A \& Kreis H (1987). Cytomegalovirus infection in fifty-two renal transplant recipients. Transplantation Proceedings, 19: 2131-2132.

29. J ohnson PC, Lewis RM, Golden DL, Oefinger PE, van Buren CT, Kerman RH \& Kahan BD (1988). The impact of cytome- galovirus infection on seronegative recipients treated with cyclosporine-prednisone immunosuppression. Transplantation, 45: 116-121.

30. Mathiesen T, Brattstrom C, Anderson J, Linde A, Ljungman P \& Wahren B (1992). Immunoglobulin $G$ subclasses and lymphocyte stimulatory responses to cytomegalovirus in transplant patients with primary cytomegalovirus infections. J ournal of Medical Virology, 36: 65-69.

31. Pannuti CS (1984). Infecção por citomegalovirus. Pediatria, 6: 144-153.

32. Smiley ML, Wlodaver CG, Grossman RA, Barker CF, Perlloff LJ, Tustin NB, Starr SE, Plotkin SA \& Friedman HM (1985). The role of pre-transplant immunity in protection from cytomegalovirus disease following renal transplantation. Transplantation, 40: 157-161.

33. Weir MR, Henry ML, Blackmore M, Smith J , First R, Irwin B, Shen S, Genemans G, Alexander JW, Corry RJ, Nghiem DD, Ferguson RM, Kittur D, Shield SF, Sommer BG \& Willians GM (1988). Incidence and morbidity of cytomegalovirus disease associated with a seronegative recipient receiving seropositive donorspecific transfusion and living related donor transplantation. Transplantation, 45: 111-116.

34. Simmons RL, Lopez C, Balfour J r HH, Kalis J, Rattazzi LC \& Najarian J S (1974). Cytomegalovirus: clinical virological correlations in renal transplant recipients. Annals of Surgery, 180: 623-634.

35. Ianhez LE, Sarturi PS, Paula FJ \& Sabbaga E (1984). Infecção por citomegalovirus pós transplante renal. Revista do Hospital das Clínicas da Faculdade de Medicina de São Paulo, USP, 39: 47-53.

36. Suassuna JHR, Ruzany F, Souza ERM, Sampaio J C \& Machado RD (1990). Correlações clínico-virológicas nos quadros infecciosos causados por citomegalovirus em pacientes com transplantes renais. Revista de Microbiologia, 21: 199-205. 